\title{
ANALISIS KUALITAS PELAYANAN PUBLIK DALAM MEMBERIKAN KEPUASAN KEPADA MASYARAKAT PADA PUSKESMAS LEMPAKE KOTA SAMARINDA
}

\author{
Oleh : \\ Salasiah, Beni Azhar ${ }^{1}$
}

Dosen Fakultas Ekonomi Universitas 17 Agustus 1945 Samarinda

${ }^{1}$ Alumni Fakultas Ilmu Sosial dan Ilmu Politik Universitas 17 Agustus 1945 Samarinda,

\begin{abstract}
In Law Number 36 Year 2009 explains that health is a healthy, physical, mental, spiritual and social condition that enables everyone to live productively socially and economically. And it has also been established that everyone is entitled to health care. Therefore, every element of society, individuals, families, are entitled to health services and the government is responsible for declaring, arranging to organize and supervise health care equally and reachable by the community.

The purpose of this research is to know the level of quality of Puskesmas service in Lempake Kota Samarinda area. the research approach used is quantitative, the unit of analysis in this study are individuals. With descriptive qualitative methods with data collection techniques through questionnaires to patients and direct survey to obtain the necessary data about how the quality of health services in Puskesmas.

The result of the research on the quality of health service of Puskesmas in Lempake area of Samarinda City is measured by using 5 dimensions of public service quality namely Tangible Evidence, Reliability, Responsiveness, Assurance and Empathy. The service performed by Puskesmas Lempake Kota Samarinda has been effective because it has received good appraisal by the society based on the five assessment indicators used, this is indicated by the recapitulation of five indicators of service quality is already above $60 \%$, it shows that the quality of health services provided is good
\end{abstract}

Keywords: Puskesmas, Lempake Samarinda, Quality of Service

\footnotetext{
${ }^{1}$ Alumni Fisipol Untag 1945 Samarinda
} 


\section{PENDAHULUAN}

\section{A. Latar Belakang}

Pemberian pelayanan publik oleh aparatur pemerintah kepada masyarakat sebenarnya merupakan implikasi dari fungsi aparat negara sebagai pelayan masyarakat. Karena itu, kedudukan aparatur pemerintah dalam pelayanan umum (public services) sangat strategis karena akan sangat menentukan sejauhmana pemerintah mampu memberikan pelayanan yang sebaik-baiknya bagi masyarakat, yang dengan demikian akan menentukan sejauhmana negara telah menjalankan perannya dengan baik sesuai dengan tujuan pendiriannya.

Dipandang dari sudut ekonomi, pelayanan merupakan salah satu alat pemuas kebutuhan manusia sebagaimana halnya dengan barang. Namun pelayanan memiliki karakteristik tersendiri yang berbeda dari barang. Salah satu yang membedakannya dengan barang, sebagaimana dikemukakan oleh Gasperz (2004), adalah outputnya yang tidak berbentuk (intangible output), tidak standar, serta tidak dapat disimpan dalam inventori melainkan langsung dapat dikonsumsi pada saat produksi.

Karakteristik pelayanan sebagaimana yang dikemukakan Gasperz tadi secara jelas membedakan pelayanan dengan barang, meskipun sebenarnya kaduanya merupakan alat pemuas kebutuhan. Sebagai suatu produk yang intangible, pelayanan memiliki dimensi yang berbeda dengan barang yang bersifat tangible. Produk akhir pelayanan tidak memiliki karakteristik fisik sebagaimana yang dimiliki oleh barang. Produk akhir pelayanan sangat tergantung dari proses interaksi yang terjadi antara layanan dengan konsumen.

Dalam konteks pelayanan publik, dikemukakan bahwa pelayanan umum adalah mendahulukan kepentingan umum, mempermudah urusan publik, mempersingkat waktu pelaksanaan urusan publik dan memberikan kepuasan kepada publik (publik/umum). Senada dengan itu, Moenir (2002) mengemukakan bahwa pelayanan publik adalah kegiatan yang dilakukan oleh seseorang atau sekelompok orang dengan landasan faktor material melalui sistem, prosedur dan metode tertentu dalam usaha memenuhi kepentingan orang lain sesuai dengan haknya.

Berangkat dari persoalan mempertanyakan kepuasan masyarakat terhadap apa yang diberikan oleh pelayan dalam hal ini yaitu administrasi publik adalah pemerintah itu sendiri dengan apa yang mereka inginkan, maksudnya yaitu sejauhmana publik berharap apa yang akhirnya diterima mereka. Demi untuk menjamin terpenuhinya hak-hak masyarakat akan pelayanan publik maka diperlukan suatu standar penilaian merngenai analisis kualitas pelayanan publik yang telah dijalankan. 


\section{B. Permasalahan}

"Bagaimana tingkat Kualitas Pelayanan Publik dalam Memberikan kepuasan kepada Masyarakat pada Puskesmas Lempake Kota Samarinda?"

\section{METODE PENELITIAN}

Pengumpulan data mulai dilaksanakan pada bulan Febfuari 2018 sampai Maret 2018 dengan menyebarkan kuesioner dan mengambil data sekunder yang diperlukan seperti struktur organisasi, jumlah pegawai, tugas pokok dan fungsi, dan lain-lain yang dibutuhkan dalam penelitian ini.

Analisis data menurut (Sanapiah Faisal $(2001 ; 255)$ terdiri dari tiga alur kegiatan yaitu :

1. Reduksi data (data reduction) yang merupakan proses merangkum, mengiktisarkan atau menyeleksi data dari catatan lapangan yang kemudian dimasukkan dalam kategori tema yang mana, fokus atau konsen pada permasalahan yang mana sesuai dengan fokus penelitian.

2. Penyajian data (data display) merupakan proses penyajian data kedalam sejumlah matrik yang sesuai yang berfungsi untuk memetakan data yang telah direduksi, juga untuk memudahkan mengkonstruksi ke dalam rangka, menuturkan, menyimpulkan dan menginterprestasikan data.

3. Menarik kesimpulan, yaitu membuat suatu kesimpulan sementara yang dapat dijadikan sebagai suatu pembekalan dalam melaksanakan penelitian untuk memberikan penafsiran dari data yang diperoleh terurama data yang berhubungan dengan fokus penelitian. Penarikan kesimpulan atau verifikasi dilakukan dengan longgar, tetap terbuka tetapi semakin lama semakin rinci, berdasarkan kesimpulan-kesimpulan data yang diperoleh dilapangandan mengakar dengan kokoh. Data yang diperoleh dilapangan, disajikan sedemikian rupa, kemudian dianalisia terhadap data tersebut untuk memperoleh hasil yang sebenarnya.

Jawaban dari setiap bagian instrument yang menggunakan skala likert mempunyai pertanyaan yang diajukan kepada responden diberi gradasi dari sangat setuju/ selalu/ sangat positif, setuju/ sering/ positif, , tidak setuju/ hampir tidak pernah/ negative, sangat tidak setuju/ tidak pernah atau gradasi lain yang disesuaikan dengan pertanyaan kuesioner yang diajukan.

Pemberian skor dimulai dari skor tertinggi dengan skor 4 hingga terendah dengan skor 1. Klasifikasi sebutan dengan kategori tersebut sebagai berikut:

1. Sangat setuju/selalu/sangat positif diberi skor

2. Setuju/sering/positif diberi skor

3. Tidak setuju/hampir tidak pernah/negative diberi skor

4. Sangat tidak setuju/tidak pernah diberi skor

Selanjutnya untuk mengetahui kualitas pelayanan kesehatan puskesmas Lempake dapat diklasifikasikan kedalam empat kelompok : 
1. Sangat baik

2. Baik

3. Cukup baik

4. Tidak baik

5. Sangat Tidak Baik

Selain itu dalam mengan

untuk mengetahui rata-rata jawaban responden pada setiap kategori pertanyaan dengan bantuan tabel frekuensi dan analisis persentase (Singarimbun dan Effendy, 2005). Dengan rumus :

$$
X=\frac{\sum(F \cdot X)}{N}
$$

Dimana : $\mathrm{X}$

$=$ Rata-rata

$$
\begin{array}{ll}
\sum_{\mathrm{N}}(\mathrm{F} . \mathrm{X}) & =\text { Jumlah skor kategori jawaban } \\
& =\text { Banyaknya responden }
\end{array}
$$

Rata-rata persen

$$
=\frac{\text { Rata-rata skor }}{\text { Banyaknya klasifikasi jawaban }} \times 100
$$

\section{HASIL PENELITIAN DAN PEMBAHASAN}

Dalam penelitian ini penulis mengambil 78 responden yang merupakan pasien yang berobat di Puskesmas Lempake. Dari hasil penelitian yang dilakukan terhadap 78 responden terdiri 47 perempuan dan 31 laki-laki. Pendidikan dari SMP- Sarjana.

Tabel 3.11 Karakteristik Responden Berdasarkan Umur

\begin{tabular}{|c|c|c|c|}
\hline No & Klasifikasi Umur & Jumlah & $(\mathbf{\% )}$ \\
\hline 1 & Dibawah 20 tahun & - & - \\
\hline 2 & $20-30$ tahun & 23 & 29.5 \\
\hline 3 & $31-40$ tahun & 35 & 44.9 \\
\hline 4 & $41-50$ tahun & 11 & 14.1 \\
\hline 5 & 51 tahun ke atas & 9 & 11.5 \\
\hline \multicolumn{2}{|r|}{ Jumlah } & $\mathbf{7 8 ~ o r a n g}$ & $\mathbf{1 0 0}$ \\
\hline
\end{tabular}

Sumber : Data yang dioleh penelitian

Pada proses pengambilan data, observasi serta penelitian yang dilakukan banyak hambatan-hambatan yang dialami penyusun. Hambatan itu antara lain data-data sekunder di Puskesmas Lempake sangat terbatas, sehingga menyulitkan peneliti, Masyarakat pun yang menjadi responden 
dalam penelitian ini banyak yang menolak untuk dimintai mengisi pertanyaan penelitian (kuisioner) dengan alasan lagi sibuk, dan sebagainya.

Untuk menganalisis kualitas pelayanan kesehatan di Puskesmas Lempake, penulis memilih 5 dimensi kualitas yang dikemukakan oleh Zeithaml, Berry dan Parasuraman yaitu ketampakan fisik (tangibles), keandalan (reliability), daya tanggap (Responsiveness), jaminan (assurance) dan empati (empathy).

\section{A. Ketampakan Fisik (Tangibles)}

Usaha pemberian pelayanan yang baik oleh penyedia layanan harus didukung oleh fasilitas baik fisik maupun non-fisik. Pemenuhan kebutuhan dalam pelayanan publik seharusnya ditangani oleh tenaga ahli sehingga pelayanan yang diberikan benar-benar memberikan pemenuhan terhadap apa yang dibutuhkan oleh pengguna layanan. Selain itu, untuk menunjang pelayanan, dibutuhkan juga fasilitas fisik. Fasilitas fisik yang lengkap dan berkualitas akan membantu memberi kepuasaan bagi pengguna layanan. Tabel 3.12. Tanggapan responden mengenai lokasi puskesmas

\begin{tabular}{|c|c|c|c|c|c|}
\hline No. & Tanggapan Responden & Skor $(\mathrm{X})$ & $\mathrm{F}$ & F.X & $\%$ \\
\hline 1 & Sangat Strategis & 4 & 37 & 148 & 47.4 \\
\hline 2 & Strategis & 3 & 40 & 120 & 51.3 \\
\hline 3 & Tidak Strategis & 2 & 1 & 2 & 1.3 \\
\hline 4 & Sangat Tidak Strategis & 1 & - & - & - \\
\hline \multicolumn{3}{|c|}{ Total } & 78 & 270 & 100 \\
\hline
\end{tabular}

Sumber : Data yang diolah dari data primer penelitian

Lokasi Puskesmas yang berada strategis yang juga dilalui oleh angkutan umum sehingga mudah di jangkau, selain itu disekitar Puskesmas juga terdapat banyak warung makan dan penjual eceran makanan ringan jika mereka tiba-tiba membutuhkannya.

Tabel 3.13 Tanggapan responden mengenai kerapihan dan kebersihan penampilan petugas

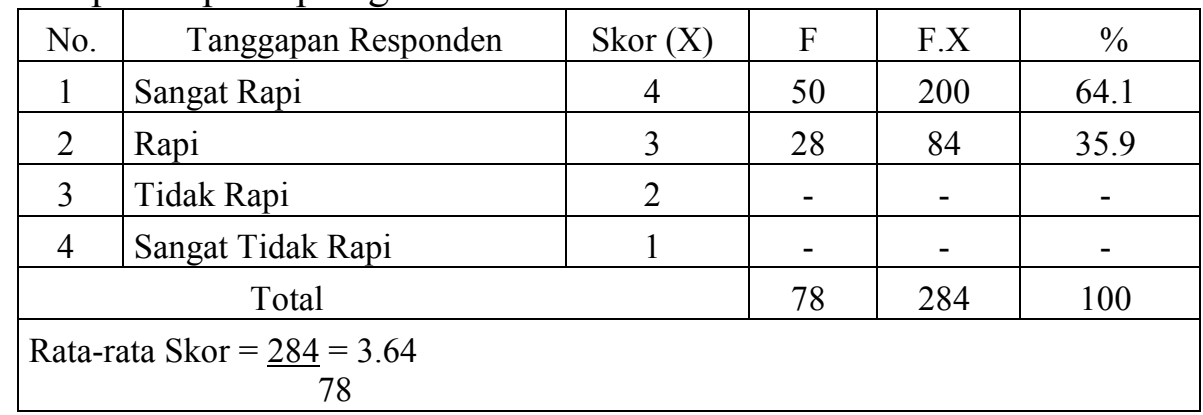

Sumber : Data yang diolah dari data primer penelitian 
Tabel 3.14 Tanggapan responden mengenai ketersediaan ruang tunggu yang bersih dan nyaman

\begin{tabular}{|c|l|c|c|c|c|}
\hline No. & \multicolumn{1}{|c|}{ Tanggapan Responden } & Skor (X) & F & F.X & $\%$ \\
\hline 1 & Sangat Nyaman & 4 & 46 & 184 & 60 \\
\hline 2 & Nyaman & 3 & 31 & 93 & 40 \\
\hline 3 & Tidak Nyaman & 2 & - & - & - \\
\hline 4 & Sangat Tidak Nyaman & 1 & - & - & - \\
\hline \multicolumn{2}{|c|}{ Total } \\
\hline Rata-rata Skor $=\underset{277}{78} 3.55$ & 78 & 277 & 100 \\
\hline
\end{tabular}

Sumber : Data yang diolah dari data primer penelitian

Dalam pengamatan penulis memang ruangan tunggu yang tersedia terasa nyaman dikarenakan fasilitas yang ada seperti kursi tunggu, kipas angin, poster tentang kesehatan tertata dengan rapi sehingga pasien merasa nyaman saat menunggu antrian dan juga luas ruang tunggu sudah sangat memadai dengan jumlah pasien yang datang, dengan kata lain tidak ada pasien yang tidak mendapatkan kursi selama menunggu antrian.

Tabel 3.15. Tanggapan responden mengenai ketersediaan ruang pemeriksaan yang memadai

\begin{tabular}{|c|l|c|c|c|c|}
\hline No. & Tanggapan Responden & Skor $(X)$ & F & F.X & $\%$ \\
\hline 1 & Sangat Memadai & 4 & 39 & 156 & 50 \\
\hline 2 & Memadai & 3 & 39 & 117 & 50 \\
\hline 3 & Tidak Memadai & 2 & - & - & - \\
\hline 4 & Sangat Tidak Memadai & 1 & - & - & - \\
\hline \multicolumn{7}{|c|}{ Total } \\
\hline Rata-rata Skor $=273=3.5$ & & 78 & 273 & 100 \\
\hline
\end{tabular}

Sumber : Data yang diolah dari data primer penelitian

Tabel 3.16.Tanggapan responden mengenai ketersediaan fasilitas pemeriksaan dan perawatan memadai

\begin{tabular}{|c|l|c|c|c|c|}
\hline No. & \multicolumn{1}{|c|}{ Tanggapan Responden } & Skor $(\mathrm{X})$ & F & F.X & $\%$ \\
\hline 1 & Sangat Memadai & 4 & 39 & 156 & 50 \\
\hline 2 & Memadai & 3 & 39 & 117 & 50 \\
\hline 3 & Tidak Memadai & 2 & - & - & - \\
\hline 4 & Sangat Tidak Memadai & 1 & - & - & - \\
\hline \multicolumn{2}{|}{ Total } & 78 & 278 & 273 \\
\hline Rata-rata Skor $=\underset{78}{78.5}$ & & \\
\hline
\end{tabular}

Sumber : Data yang diolah dari data primer penelitian 
Tabel 4.17 Rekapitulasi tanggapan responden mengenai dimensi Ketampakan Fisik (Tangibility)

\begin{tabular}{|c|l|c|c|}
\hline No. & \multicolumn{1}{|c|}{ Tanggapan Responden } & Rata-rata Skor & Rata-rata (\%) \\
\hline 1 & Lokasi Puskesmas mudah dijangkau. & 3.46 & 69.23 \\
\hline 2 & $\begin{array}{l}\text { Kerapihan dan kebersihan penampilan } \\
\text { petugas. }\end{array}$ & 3.64 & 72.82 \\
\hline 3 & $\begin{array}{l}\text { Ketersediaan ruang tunggu yang bersih dan } \\
\text { nyaman. }\end{array}$ & 3.55 & 71.03 \\
\hline 4 & $\begin{array}{l}\text { Ketersediaan ruangan pemeriksaan yang } \\
\text { memadai. }\end{array}$ & 3.50 & 70 \\
\hline 5 & $\begin{array}{l}\text { Ketersediaan fasilitas pemeriksaan dan } \\
\text { perawatan. }\end{array}$ & 3.50 & 70.69 \\
\hline & Rata-rata skor dan rata-rata persentase & 38 \\
\hline
\end{tabular}

Sumber : Data yang diolah dari data primer penelitian

Berdasarkan data diatas yang merupakan rekapitulasi dari kelima poin dari dimensi ketampakan fisik (tangibility) maka dapat dikatakan baik, hal ini dapat dilihat dari rata-rata persentase rekapitulasi sebesar 70,69\%. Ketampakan fisik (Tangibles) dari gedung, peralatan, pegawai dan fasilitasfasilitas lain yang dimiliki oleh Puskesmas Lempake, seperti lokasi puskesmas, petugas berpenampilan rapi dan bersih, ruang tunggu yang cukup nyaman, ruangan pemeriksaan serta fasilitas pemeriksaan dan perawatan sudah memadai.

\section{B. Keandalan (Reliability)}

Proses pemberian pelayanan publik pada dasarnya harus dilakukan sesuai dengan prinsip-prinsip atau ketentuan-ketentuan administrasi organisasi yang benar dan telah ditetapkan. Keandalan (Reliability) adalah kemampuan untuk menyelenggarakan pelayanan yang dijanjikan secara konsisten dan akurat. Hal ini penting mengingat masyarakat membutuhkan pembuktian dari janji-janji pelayanan.

Tabel 3.18. Tanggapan responden mengenai ketanggapan petugas terhadap keluhan pasien

\begin{tabular}{|c|c|c|c|c|c|}
\hline No. & Tanggapan Responden & Skor $(\mathrm{X})$ & $\mathrm{F}$ & F.X & $\%$ \\
\hline 1 & Sangat Tanggap & 4 & 29 & 116 & 37.2 \\
\hline 2 & Tanggap & 3 & 40 & 120 & 51.3 \\
\hline 3 & Tidak Tanggap & 2 & 9 & 18 & 11.5 \\
\hline 4 & Sangat Tidak Tanggap & 1 & - & - & - \\
\hline \multicolumn{2}{|r|}{ Total } & & 78 & 250 & 100 \\
\hline \multicolumn{6}{|c|}{ Rata-rata Skor $=\underline{356}=3.26$} \\
\hline
\end{tabular}

Sumber : Data yang diolah dari data primer penelitian 
Tabel 3.19. Tanggapan responden mengenai proses waktu pendaftaran yang cepat

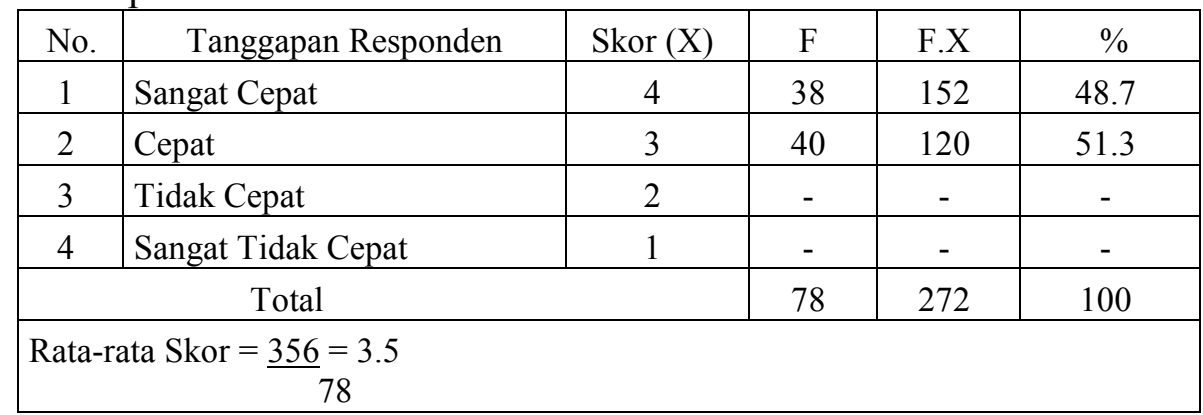

Sumber : Data yang diolah dari data primer penelitian

Tabel 3.20 Tanggapan responden mengenai proses waktu pengobatan yang cepat

\begin{tabular}{|c|l|c|c|c|c|}
\hline No. & \multicolumn{1}{|c|}{ Tanggapan Responden } & Skor $(\mathrm{X})$ & F & F.X & $\%$ \\
\hline 1 & Sangat Cepat & 4 & 30 & 120 & 38.5 \\
\hline 2 & Cepat & 3 & 39 & 117 & 50 \\
\hline 3 & Tidak Cepat & 2 & 9 & 18 & 11.5 \\
\hline 4 & Sangat Tidak Cepat & 1 & - & - & - \\
\hline \multicolumn{2}{|}{ Total } & 89 & 255 & 100 \\
\hline Rata-rata Skor $=\underline{255}=3.27$ & & \\
\hline
\end{tabular}

Sumber : Data yang diolah dari data primer penelitian

Berdasarkan hasil dari pengamatan penulis, pelayanan yang diberikan selama pemeriksaan cukup cepat tergantung dari seberapa tingkat keluhan pasien, menurut beberapa responden memberikan tanggapan kalau dalam mendapatkan pelayanan dari petugas cepat dan sesuai dengan yang diharapkan meskipun terkadang pasien harus berobat berulang kali demi pengobatan yang maksimal walaupun sebenarnya sudah tidak perlu, tetapi secara keseluruhan pelayanan yang diberikan sudah cepat.

Tabel 3.21 Tanggapan responden mengenai kemudahan layanan informasi

\begin{tabular}{|c|c|c|c|c|c|}
\hline No. & Tanggapan Responden & Skor (X) & $\mathrm{F}$ & F.X & $\%$ \\
\hline 1 & Sangat Mudah & 4 & 30 & 120 & 38.5 \\
\hline 2 & Mudah & 3 & 39 & 117 & 50 \\
\hline 3 & Tidak Mudah & 2 & 9 & 18 & 11.5 \\
\hline 4 & Sangat Tidak Mudah & 1 & - & - & - \\
\hline \multicolumn{3}{|c|}{ Total } & 78 & 255 & 100 \\
\hline \multicolumn{6}{|c|}{ Rata-rata Skor $=\underline{255}=3.27$} \\
\hline
\end{tabular}

Sumber : Data yang diolah dari data primer penelitian 
Berdasarkan hasil pengamatan yang penulis lakukan bahwa kemudahan layanan informasi cukup mudah didapatkan meskipun ada sebagian kecil pasien yang mengeluh dikarenakan tidak mendapatkan sosialisasi dari pihak Puskesmas Lempake, mengenai program-program yang dicanangkan pemerintah baik pusat maupun daerah. Misalnya sosialisasi mengenai BPJS, masih banyak pasien/masyarakat yang belun mengerti mengenai program tersebut.

Tabel 3.22. Tanggapan responden mengenai kesiapan petugas setiap saat diperlukan

\begin{tabular}{|c|c|c|c|c|c|}
\hline No. & Tanggapan Responden & Skor (X) & $\mathrm{F}$ & F.X & $\%$ \\
\hline 1 & Sangat Siap & 4 & 25 & 100 & 32.1 \\
\hline 2 & Siap & 3 & 45 & 135 & 57.7 \\
\hline 3 & Tidak Siap & 2 & 8 & 16 & 10.3 \\
\hline 4 & Sangat Tidak Siap & 1 & - & - & - \\
\hline \multicolumn{3}{|c|}{ Total } & 78 & 251 & 100 \\
\hline \multicolumn{6}{|c|}{ Rata-rata Skor $=\underline{251}=3.22$} \\
\hline
\end{tabular}

\section{Sumber : Data yang diolah dari data primer penelitian}

Tabel 3.23 Tanggapan responden mengenai pengetahuan dan keterampilan pegawai dalam memberikan layanan.

\begin{tabular}{|c|c|c|c|c|c|}
\hline No. & Tanggapan Responden & Skor (X) & $\mathrm{F}$ & F.X & $\%$ \\
\hline 1 & Sangat Baik & 4 & 5 & 20 & 6.4 \\
\hline 2 & Baik & 3 & 73 & 219 & 93.6 \\
\hline 3 & Tidak Baik & 2 & - & - & - \\
\hline 4 & Sangat Tidak Baik & 1 & - & - & - \\
\hline \multicolumn{3}{|c|}{ Total } & 78 & 239 & 100 \\
\hline
\end{tabular}

Sumber : Data yang diolah dari data primer penelitian

Tabel 3.24 Rekapitulasi tanggapan responden mengenai dimensi Keandalan (Reliability)

\begin{tabular}{|c|l|c|c|}
\hline No. & \multicolumn{1}{|c|}{ Tanggapan Responden } & Rata-rata Skor & Rata-rata (\%) \\
\hline 1 & Petugas tanggap terhadap keluhan pasien. & 3.26 & 64.10 \\
\hline 2 & $\begin{array}{l}\text { Proses waktu layanan pendaftaran yang } \\
\text { cepat. }\end{array}$ & 3.50 & 69.74 \\
\hline 3 & $\begin{array}{l}\text { Proses waktu layanan pengobatan yang } \\
\text { cepat. }\end{array}$ & 3.27 & 65.38 \\
\hline 4 & Kemudahan layanan informasi Puskesmas. & 3.27 & 65.38 \\
\hline 5 & Petugas selalu siap sedia saat di-perlukan. & 3.22 & 64.36 \\
\hline
\end{tabular}




\begin{tabular}{|c|l|c|c|}
\hline 6 & $\begin{array}{l}\text { Pengetahuan dan keterampilan pegawai } \\
\text { dalam memberikan layanan. }\end{array}$ & 3.06 & 61.28 \\
\hline \multicolumn{2}{|c|}{ Rata-rata skor dan rata-rata persentase } & 3.26 & 65.04 \\
\hline
\end{tabular}

Sumber : Data yang diolah dari data primer penelitian

Ketanggapan petugas terhadap keluhan pasien sudah cukup baik, kesiapan petugas setiap kali dibutuhkan hampir selalu ada, pelayanan yang diberikan selama pemeriksaan cukup cepat tergantung dari seberapa tingkat keluhan pasien, menurut beberapa responden memberikan tanggapan kalau dalam mendapatkan pelayanan dari petugas cepat dan sesuai dengan yang diharapkan.

\section{Daya Tanggap (Responsiveness)}

Dalam pemberian pelayanan kepada masyarakat petugas pelayanan seharusnya memiliki kesediaan untuk membantu masyarakat/pelanggan/ pasien dengan menyediakan pelayanan yang cocok seperti yang mereka harapkan. Ketidakjelasan prosedur serta membiarkan pelanggan/pasien menunggu lama tanpa alasan yang jelas dapat menyebabkan persepsi yang negatif terhadap kualitas pelayanan publik, termasuk ketidakmampuan untuk segera mengatasi hal tersebut.

Dimensi Daya Tanggap (Responsiveness) dalam upaya untuk mengetahui kualitas pelayanan Kesehatan di Puskesmas Lempake dapat dilihat pada tabel berikut :

Tabel 3.25 Tanggapan responden mengenai ketanggapan petugas dalam melayani pasien

\begin{tabular}{|c|c|c|c|c|c|}
\hline No. & Tanggapan Responden & Skor $(\mathrm{X})$ & $\mathrm{F}$ & F.X & $\%$ \\
\hline 1 & Sangat Tanggap & 4 & 21 & 84 & 26.9 \\
\hline 2 & Tanggap & 3 & 57 & 171 & 73.1 \\
\hline 3 & Tidak Tanggap & 2 & - & - & - \\
\hline 4 & Sangat Tidak Tanggap & 1 & - & - & - \\
\hline \multicolumn{3}{|c|}{ Total } & 78 & 255 & 100 \\
\hline \multicolumn{6}{|c|}{ Rata-rata Skor $=\underline{255}=3.27$} \\
\hline
\end{tabular}

Sumber: Data yang diolah dari data primer penelitian

Berdasarkan data tersebut diatas, ketanggapan petugas yang ada di Puskesmas Lempake sudah sangat tanggap dalam memenuhi kebutuhan pasien. Ketanggapan petugas dalam memberikan pelayanan kepada pasien harus dimiliki oleh semua petugas puskesmas Lempake agar pasien tidak merasa kesulitan dalam mendapatkan pelayanan. Ketanggapan petugas dalam memberikan pelayanan kepada pasien akan memberikan kepuasan tersendiri bagi pasien. 
Tabel 3.26 Tanggapan responden mengenai pelayanan puskesmas mudah dan tidak berbelit-belit

\begin{tabular}{|c|c|c|c|c|c|}
\hline No. & Tanggapan Responden & Skor $(\mathrm{X})$ & $\mathrm{F}$ & F.X & $\%$ \\
\hline 1 & Sangat Mudah & 4 & 9 & 36 & 11.5 \\
\hline 2 & Mudah & 3 & 68 & 204 & 87.2 \\
\hline 3 & Tidak Mudah & 2 & 1 & 2 & 1.3 \\
\hline 4 & Sangat Tidak Mudah & 1 & - & - & - \\
\hline \multicolumn{3}{|c|}{ Total } & 78 & 242 & 100 \\
\hline \multicolumn{6}{|c|}{ Rata-rata Skor $=\frac{242}{78}=3.10$} \\
\hline
\end{tabular}

Sumber : Data yang diolah dari data primer penelitian

Tabel 3.27 Tanggapan responden mengenai kemampuan petugas melayani dengan baik

\begin{tabular}{|c|l|c|c|c|c|}
\hline No. & Tanggapan Responden & Skor (X) & F & F.X & $\%$ \\
\hline 1 & Sangat Baik & 4 & 20 & 80 & 25.6 \\
\hline 2 & Baik & 3 & 55 & 165 & 70.5 \\
\hline 3 & Tidak Baik & 2 & 3 & 6 & 3.9 \\
\hline 4 & Sangat Tidak Baik & 1 & - & - & - \\
\hline \multicolumn{2}{|r|}{ Total } & 78 & 251 & 100 \\
\hline Rata-rata Skor $=251=3.22$ \\
\cline { 2 - 2 }
\end{tabular}

Sumber : Data yang diolah dari data primer penelitian

Tabel 3.28 Tanggapan responden mengenai tindakan segera petugas dalam menyelesaikan masalah

\begin{tabular}{|c|c|c|c|c|c|}
\hline No. & Tanggapan Responden & Skor $(\mathrm{X})$ & $\mathrm{F}$ & F.X & $\%$ \\
\hline 1 & Sangat Cepat & 4 & 24 & 96 & 30.8 \\
\hline 2 & Cepat & 3 & 50 & 150 & 64.1 \\
\hline 3 & Tidak Cepat & 2 & 4 & 8 & 5.1 \\
\hline 4 & Sangat Tidak Cepat & 1 & - & - & - \\
\hline \multicolumn{3}{|c|}{ Total } & 78 & 254 & 100 \\
\hline
\end{tabular}

Sumber : Data yang diolah dari data primer penelitian

Tabel 3.29 Tanggapan responden mengenai petugas memberikan informasi yang jelas dan mudah dimengerti.

\begin{tabular}{|c|l|c|c|c|c|}
\hline No. & \multicolumn{1}{|c|}{ Tanggapan Responden } & Skor $(\mathrm{X})$ & F & F.X & $\%$ \\
\hline 1 & Sangat Jelas & 4 & 24 & 96 & 30.8 \\
\hline
\end{tabular}




\begin{tabular}{|c|l|c|c|c|c|}
\hline 2 & Jelas & 3 & 51 & 153 & 65.4 \\
\hline 3 & Tidak Jelas & 2 & 3 & 6 & 3.8 \\
\hline 4 & Sangat Tidak Jelas & 1 & - & - & - \\
\hline \multicolumn{2}{|c|}{ Total } & 78 & 255 & 100 \\
\hline Rata-rata Skor $=\underset{255}{78} 3.27$ & & \\
\hline
\end{tabular}

Sumber : Data yang diolah dari data primer penelitian

Tabel 3.30 Rekapitulasi tanggapan responden mengenai dimensi Daya Tanggap (Responsiveness)

\begin{tabular}{|c|c|c|c|}
\hline No. & Tanggapan Responden & $\begin{array}{l}\text { Rata-rata } \\
\text { Skor }\end{array}$ & $\begin{array}{l}\text { Rata-rata } \\
(\%)\end{array}$ \\
\hline 1 & $\begin{array}{l}\text { Kemampuan petugas medis untuk cepat tanggap } \\
\text { melayani pasien. }\end{array}$ & 3.27 & 65.38 \\
\hline 2 & $\begin{array}{l}\text { Pelayanan Puskesmas mudah dan tidak berbelit- } \\
\text { belit. }\end{array}$ & 3.10 & 62.05 \\
\hline 3 & $\begin{array}{l}\text { Petugas mampu memberikan pelayanan dengan } \\
\text { baik. }\end{array}$ & 3.22 & 64.35 \\
\hline 4 & $\begin{array}{l}\text { Tindakan segera petugas dalam menyelesaikan } \\
\text { masalah. }\end{array}$ & 3.26 & 65.13 \\
\hline 5 & $\begin{array}{l}\text { Petugas memberikan informasi yang jelas dan } \\
\text { mudah dimengerti. }\end{array}$ & 3.27 & 65.38 \\
\hline & Rata-rata skor dan rata-rata persentase & 3.22 & 64.46 \\
\hline
\end{tabular}

Sumber : Data yang diolah dari data primer penelitian

\section{Jaminan (Assurance)}

Dimensi jaminan (Assurance) merupakan keahlian dan pengetahuan pegawai dalam memberikan layanan serta kemampuan mereka untuk meyakinkan masyarakat terhadap kompetensi dan kredibilitas yang dimiliki. Dimensi Jaminan (Assurance) dalam upaya untuk mengetahui kualitas pelayanan Kesehatan di Puskesmas Lempake dapat dilihat dari tabel berikut : Tabel 3.31 Tanggapan responden mengenai petugas jujur dalam hal pelayanan

\begin{tabular}{|c|l|c|c|c|c|}
\hline No. & Tanggapan Responden & Skor (X) & F & F.X & $\%$ \\
\hline 1 & Sangat Jujur & 4 & 9 & 36 & 11.5 \\
\hline 2 & Jujur & 3 & 68 & 205 & 87.2 \\
\hline 3 & Tidak Jujur & 2 & 12 & 24 & 15.4 \\
\hline 4 & Sangat Tidak Jujur & 1 & - & - & - \\
\hline \multicolumn{2}{|r|}{ Total } & 78 & 265 & 100 \\
\hline Rata-rata Skor $=\underset{265}{78} 3.4$ &
\end{tabular}

Sumber : Data yang diolah dari data primer penelitian 
Tabel 3.32 Tanggapan responden mengenai petugas selalu melaksanakan pelayanan secara tuntas dan menyeluruh

\begin{tabular}{|c|l|c|c|c|c|}
\hline No. & Tanggapan Responden & Skor $(X)$ & F & F.X & $\%$ \\
\hline 1 & Sangat Tuntas & 4 & 23 & 92 & 29.5 \\
\hline 2 & Tuntas & 3 & 50 & 150 & 64.1 \\
\hline 3 & Tidak Tuntas & 2 & 5 & 10 & 6.4 \\
\hline 4 & Sangat Tidak Tuntas & 1 & - & - & - \\
\hline \multicolumn{2}{|r}{ Total } & 78 & 252 & 100 \\
\hline Rata-rata Skor $=252=3,23$ \\
\end{tabular}

Sumber : Data yang diolah dari data primer penelitian

Tabel 3.33 Tanggapan responden mengenai petugas bertindak ramah dan sopan dalam melayani.

\begin{tabular}{|c|c|c|c|c|c|}
\hline No. & Tanggapan Responden & Skor (X) & $\mathrm{F}$ & F.X & $\%$ \\
\hline 1 & Sangat Ramah & 4 & 18 & 72 & 23.1 \\
\hline 2 & Ramah & 3 & 55 & 165 & 70.5 \\
\hline 3 & Tidak Ramah & 2 & 5 & 10 & 6.4 \\
\hline 4 & Sangat Tidak Ramah & 1 & - & - & - \\
\hline \multicolumn{3}{|c|}{ Total } & 78 & 247 & 100 \\
\hline
\end{tabular}

\section{Sumber : Data yang diolah dari data primer penelitian}

Petugas haruslah memiliki kemampuan untuk memahami dan mengerti keinginan pasien yang sangat mengharapkan perhatian yang lebih dan perlakuan yang ramah dari petugas. Kesopanan dalam memberikan pelayanan menjadi hal yang penting karena dengan demikian pasien dapat memberikan nilai yang baik kepada petugas. Dengan demikian maka pasien akan merasa nyaman atas pelayanan yang diterima.

Tabel 3.34 Tanggapan responden mengenai arti keberadaan puskesmas bagi pasien

\begin{tabular}{|c|l|c|c|c|c|}
\hline No. & Tanggapan Responden & Skor $(\mathrm{X})$ & F & F.X & $\%$ \\
\hline 1 & Sangat Berarti & 4 & 55 & 220 & 70.5 \\
\hline 2 & Berarti & 3 & 22 & 66 & 28.2 \\
\hline 3 & Tidak Berarti & 2 & 1 & 2 & 1.3 \\
\hline 4 & Sangat Tidak Berarti & 1 & - & - & - \\
\hline \multicolumn{2}{|r|}{ Total } & 78 & 288 & 100 \\
\hline Rata-rata Skor $=288=3.69$ \\
\cline { 2 - 2 }
\end{tabular}

Sumber : Data yang diolah dari data primer penelitian 
Tabel 3.35 Tanggapan responden mengenai kemampuan petugas melakukan komunikasi yang efektif.

\begin{tabular}{|c|c|c|c|c|c|}
\hline No. & Tanggapan Responden & Skor $(\mathrm{X})$ & $\mathrm{F}$ & F.X & $\%$ \\
\hline 1 & Sangat Baik & 4 & 17 & 68 & 21.8 \\
\hline 2 & Baik & 3 & 60 & 180 & 76.9 \\
\hline 3 & Tidak Baik & 2 & 1 & 2 & 1.3 \\
\hline 4 & Sangat Tidak Baik & 1 & - & - & - \\
\hline \multicolumn{3}{|c|}{ Total } & 78 & 250 & 100 \\
\hline
\end{tabular}

Sumber : Data yang diolah dari data primer penelitian

Komunikasi yang efektif antara petugas dan pasien merupakan hal yang sangat penting, terutama dalam hal pelayanan kesehatan, kesalahan informasi akan mengakibatkan hal yang fatal terlebih lagi dalam hal pengobatan.

Tabel 3.36 Tanggapan responden mengenai kemampuan petugas dalam memberikan pengobatan yang tepat.

\begin{tabular}{|c|c|c|c|c|c|}
\hline No. & Tanggapan Responden & Skor $(\mathrm{X})$ & $\mathrm{F}$ & F.X & $\%$ \\
\hline 1 & Sangat Baik & 4 & 17 & 68 & 21.8 \\
\hline 2 & Baik & 3 & 60 & 180 & 76.9 \\
\hline 3 & Tidak Baik & 2 & 1 & 2 & 1.3 \\
\hline 4 & Sangat Tidak Baik & 1 & - & - & - \\
\hline \multicolumn{3}{|c|}{ Total } & 78 & 250 & 100 \\
\hline
\end{tabular}

Sumber : Data yang diolah dari data primer penelitian

Tabel 3.37 Rekapitulasi tanggapan responden mengenai dimensi Jaminan (Assurance)

\begin{tabular}{|c|l|c|c|}
\hline No. & \multicolumn{1}{|c|}{ Tanggapan Responden } & $\begin{array}{c}\text { Rata-rata } \\
\text { Skor }\end{array}$ & $\begin{array}{c}\text { Rata-rata } \\
(\%)\end{array}$ \\
\hline 1 & Petugas jujur dalam hal pelayanan. & 3,4 & 67.95 \\
\hline 2 & $\begin{array}{l}\text { Petugas selalu melaksanankan } \\
\text { pelayanan secara tuntas dan menyeluruh. }\end{array}$ & 3.23 & 64.62 \\
\hline 3 & $\begin{array}{l}\text { Petugas bertindak ramah dan sopan dalam } \\
\text { melayani. }\end{array}$ & 3.17 & 63.33 \\
\hline 4 & $\begin{array}{l}\text { Arti keberadaan Puskesmas bagi pasien. } \\
\text { Kemampuan petugas melakukan komunikasi yang } \\
\text { efektif. }\end{array}$ & 3.69 & 73.85 \\
\hline 6 & $\begin{array}{l}\text { Kemampuan petugas dalam memberikan } \\
\text { pengobatan yang tepat. }\end{array}$ & 3.21 & 64.1 \\
\hline \multicolumn{2}{|l|}{ Rata-rata skor dan rata-rata persentase } & 3.32 & 66.33 \\
\hline
\end{tabular}

Sumber : Data yang diolah dari data primer penelitian 


\section{Empati (Emphaty)}

Kemudahan dan kejelasan dalam memberikan pelayanan sesuai dengan kebutuhan masing-masing masyarakat merupakan hal yang penting. Empati menyangkut pemberian pelayanan yang baik kepada pelanggan dalam hal ini keramahan, sopan santun, dan kesabaran dalam memberikan pelayanan.

Tabel 3.39 Tanggapan responden mengenai petugas memberikan pelayanan dengan tulus

\begin{tabular}{|c|c|c|c|c|c|}
\hline No. & Tanggapan Responden & Skor $(\mathrm{X})$ & $\mathrm{F}$ & F.X & $\%$ \\
\hline 1 & Sangat Tulus & 4 & 5 & 20 & 6.4 \\
\hline 2 & Tulus & 3 & 68 & 204 & 87.2 \\
\hline 3 & Tidak Tulus & 2 & 5 & 10 & 6.4 \\
\hline 4 & Sangat Tidak Tulus & 1 & - & - & - \\
\hline \multicolumn{2}{|r|}{ Total } & & 78 & 234 & 100 \\
\hline \multicolumn{6}{|c|}{ Rata-rata Skor $=\frac{234}{78}=3.00$} \\
\hline
\end{tabular}

Sumber : Data yang diolah dari data primer penelitian

Ketulusan dalam memberikan pelayanan menjadi hal yang penting bagi petugas yang bekerja di sektor publik, karena dengan memberikan pelayanan dengan tulus maka masyarakat/pasien akan merasa nyaman dengan pelayanan yang diterima, dengan demikian pasien dapat memberikan nilai yang baik kepada petugas.

Dalam sektor publik, Pegawai harus memberikan pelayanan tanpa mengharapkan imbalan dari masyarakat dan pegawai harus sadar bahwa tugas untuk melayani masyarakat merupakan tanggung jawab yang harus laksanakan.

Tabel 3.40 Tanggapan responden mengenai petugas mampu memberikan citra dan kesan yang baik.

\begin{tabular}{|c|c|c|c|c|c|}
\hline No. & Tanggapan Responden & Skor $(\mathrm{X})$ & $\mathrm{F}$ & F.X & $\%$ \\
\hline 1 & Sangat Baik & 4 & 26 & 104 & 33.3 \\
\hline 2 & Baik & 3 & 47 & 141 & 60.3 \\
\hline 3 & Tidak Baik & 2 & 5 & 10 & 6.4 \\
\hline 4 & Sangat Tidak Baik & 1 & - & - & - \\
\hline \multicolumn{3}{|c|}{ Total } & 78 & 255 & 100 \\
\hline \multicolumn{6}{|c|}{ Rata-rata Skor $=\underbrace{255}_{78}=3.27$} \\
\hline
\end{tabular}

Sumber : Data yang diolah dari data primer penelitian 
Citra dan kesan yang baik sangat berpengaruh terhadap kepuasan pelayanan yang dirasakan oleh pasien. Jika petugas mampu memberikan kesan dan citra yang baik kepada pasien maka pasienpun akan menilai petugas dengan baik pula.

Tabel 3.41 Tanggapan responden mengenai petugas bersikap adil dan tidak membeda-bedakan.

\begin{tabular}{|c|l|c|c|c|c|}
\hline No. & \multicolumn{1}{|c|}{ Tanggapan Responden } & Skor $(\mathrm{X})$ & F & F.X & $\%$ \\
\hline 1 & Sangat Adil & 4 & 8 & 32 & 10.3 \\
\hline 2 & Adil & 3 & 66 & 198 & 84.6 \\
\hline 3 & Tidak Adil & 2 & 4 & 8 & 5.1 \\
\hline 4 & Sangat Tidak Adil & 1 & - & - & - \\
\hline \multicolumn{2}{|r}{ Total } & 78 & 238 & 100 \\
\hline Rata-rata Skor $=\underline{238}=3.05$ \\
\end{tabular}

Sumber : Data yang diolah dari data primer penelitian

Tabel 4.42 Tanggapan responden mengenai perhatian petugas secara khusus kepada pasien

\begin{tabular}{|c|c|c|c|c|c|}
\hline No. & Tanggapan Responden & Skor $(\mathrm{X})$ & $\mathrm{F}$ & F.X & $\%$ \\
\hline 1 & Sangat Baik & 4 & 24 & 96 & 30.8 \\
\hline 2 & Baik & 3 & 50 & 150 & 64.1 \\
\hline 3 & Tidak Baik & 2 & 4 & 8 & 5.1 \\
\hline 4 & Sangat Tidak Baik & 1 & - & - & - \\
\hline \multicolumn{3}{|c|}{ Total } & 78 & 254 & 100 \\
\hline \multicolumn{6}{|c|}{ Rata-rata Skor $=\frac{254}{78}=3.26$} \\
\hline
\end{tabular}

Sumber : Data yang diolah dari data primer penelitian

Tabel 3.43 Tanggapan responden mengenai petugas mendengarkan dengan seksama keluhan-keluhan pasien

\begin{tabular}{|c|l|c|c|c|c|}
\hline No. & Tanggapan Responden & Skor (X) & F & F.X & $\%$ \\
\hline 1 & Sangat Baik & 4 & 20 & 80 & 25.6 \\
\hline 2 & Baik & 3 & 58 & 174 & 74.4 \\
\hline 3 & Tidak Baik & 2 & - & - & - \\
\hline 4 & Sangat Tidak Baik & 1 & - & - & - \\
\hline \multicolumn{2}{|c|}{ Total } & 78 & 258 & 100 \\
\hline Rata-rata Skor $=254=3.26$ \\
78
\end{tabular}

Sumber : Data yang diolah dari data primer penelitian 
Tabel 3.44 Tanggapan responden mengenai kesediaan petugas meminta maaf

\begin{tabular}{|c|c|c|c|c|c|}
\hline No. & Tanggapan Responden & Skor $(\mathrm{X})$ & $\mathrm{F}$ & F.X & $\%$ \\
\hline 1 & Sangat Baik & 4 & 42 & 168 & 53.8 \\
\hline 2 & Baik & 3 & 34 & 103 & 43.6 \\
\hline 3 & Tidak Baik & 2 & 2 & 4 & 2.6 \\
\hline 4 & Sangat Tidak Baik & 1 & - & - & - \\
\hline \multicolumn{3}{|c|}{ Total } & 78 & 275 & 100 \\
\hline
\end{tabular}

Sumber : Data yang diolah dari data primer penelitian 2016

Kesediaan petugas meminta maaf kepada pasien dikala membuat suatu kesalahan memberikan kepuasan tersendiri bagi pelanggan yang dilayani sekalipun petugas telah melakukan kesalahan.

Tabel 3.45 Rekapitulasi tanggapan responden mengenai dimensi Empati (Emphaty)

\begin{tabular}{|c|c|c|c|}
\hline No. & Tanggapan Responden & $\begin{array}{c}\text { Rata-rata } \\
\text { Skor }\end{array}$ & $\begin{array}{c}\text { Rata-rata } \\
(\%)\end{array}$ \\
\hline 1 & $\begin{array}{l}\text { Petugas memberikan pelayanan dengan } \\
\text { tulus. }\end{array}$ & 3 & 60 \\
\hline 2 & $\begin{array}{l}\text { Petugas mampu memberikan citra dan kesan } \\
\text { yang baik. }\end{array}$ & 3.27 & 65.38 \\
\hline 3 & $\begin{array}{l}\text { Petugas bersikap adil dan tidak membeda- } \\
\text { bedakan. }\end{array}$ & 3.05 & 61.03 \\
\hline 4 & Perhatian petugas secara khusus kepada pasien. & 3.26 & 65.13 \\
\hline 5 & $\begin{array}{l}\text { Mendengarkan dengan seksama keluhan- } \\
\text { keluhan pasien. }\end{array}$ & 3.26 & 66.15 \\
\hline 6 & Kesediaan meminta maaf. & 3.53 & 70.51 \\
\hline \multicolumn{2}{|r|}{ Rata-rata skor dan rata-rata persentase } & 3.23 & 64.7 \\
\hline
\end{tabular}

Sumber : Data yang diolah dari data primer penelitian

Tabel 3.46 Rekapitulasi kelima dimensi kualitas pelayanan

\begin{tabular}{|c|l|c|c|}
\hline No. & \multicolumn{1}{|c|}{ Indikator Kualitas Pelayanan } & Rata-rata (\%) & Kategori \\
\hline 1 & Ketampakan fisik (Tangibles) & 70.69 & Baik \\
\hline 2 & Keandalan (Reliability) & 65.04 & Baik \\
\hline 3 & Daya tanggap (Responsiveness) & 64.46 & Baik \\
\hline 4 & Jaminan (Assurance) & 66.33 & Baik \\
\hline 5 & Empati (Emphaty) & 64.7 & Baik \\
\hline
\end{tabular}

Sumber : Data yang diolah dari data primer penelitian 
Berdasarkan data pada tabel diatas menunjukan kualitas pelayanan kesehatan di Puskesmas Lempake sudah berjalan dengan baik, hal ini dapat dilihat dengan rata-rata persentase penilaian responden pada kelima dimensi kualitas pelayanan sudah berada diatas $60 \%$.

\section{PENUTUP}

\section{A. Kesimpulan}

1. Dilihat dari dimensi Ketampakan fisik (Tangibles) Puskesmas Kecamatan Lempake Kota Samarinda berada pada kategori persentase baik sehingga kualitas pelayanan kesehatan Puskesmas Lempake Kota Samarinda dinilai sudah berkualitas. Lokasi Puskesmas berada pada daerah yang strategis yang juga dilalui oleh angkutan umum, kerapian dan kebersihan penampilan petugas memberikan kepuasan tersendiri bagi pasien yang dilayani, ruangan tunggu yang tersedia terasa nyaman dikarenakan fasilitas yang ada seperti kursi tunggu, kipas angin, poster tentang kesehatan tertata dengan rapi sehingga pasien merasa nyaman saat menunggu antrian, ruangan pemeriksaan dengan ukuran yang tidak terlalu sempit dengan fasilitas pemeriksaan yang ada didalamnya memberikan kepuasan tersendiri bagi pasien. Semua poin pelayanan dari dimensi Ketampakan Fisik (Tangibles) mendapat respon yang baik dari masyarakat.

2. Dimensi Keandalan (Reliability) juga berada pada kategori persentase baik sehingga kualitas pelayanan kesehatan Puskesmas Lempake Kota Samarinda dilihat dari dimensi Keandalan (Reliability) dinilai sudah berkualitas. ketanggapan petugas terhadap keluhan pasien dinilai sudah baik, waktu layanan pendaftaran dan layanan pengobatan yang cepat, kemudahan layanan informasi Puskesmas serta kesiapan petugas sedia saat diperlukan dan keterampilan pegawai dalam memberikan layanan mendapat respon yang baik dari masyarakat/pasien.

3. Dimensi Daya Tanggap (Responsiveness) berada pada kategori persentase sangat baik sehingga kualitas pelayanan kesehatan Puskesmas Lempake Kota Samarinda dilihat dari dimensi Daya Tanggap (Responsiveness) dinilai sudah berkualitas. Kemampuan petugas untuk memahami kebutuhan masyarakat, pelayanan yang tidak berbelit-belit, memberikan pelayanan dengan baik, Tindakan segera petugas dalam menyelesaikan masalah dan memberikan informasi yang mudah dimengerti juga mendapat respon yang baik dari masyarakat.

4. Dimensi Jaminan (Ansurance) berada pada kategori persentase baik sehingga kualitas pelayanan kesehatan Puskesmas Lempake Kota Samarinda dilihat dari dimensi Jaminan (Ansurance) dinilai sudah 
berkualitas. Keseluruhan dimensi Jaminan (Ansurance) sudah baik dengan kata lain pelayanan sudah berkualitas. Kejujuran dalam hal pelayanan, pelayanan dilaksanakan secara tuntas dan menyeluruh, keramahan dan kesopanan dalam melayani, serta komunikasi yang efektif dan memberikan pengobatan yang tepat juga mendapat respon yang baik dari masyarakat.

5. Dimensi Empati (Emphaty) berada pada kategori persentase baik sehingga kualitas pelayanan kesehatan Puskesmas Lempake Kota Samarinda dilihat dari dimensi Empati (Emphaty) dinilai sudah berkualitas. Kemampuan petugas memberikan pelayanan dengan tulus memberikan citra dan kesan yang baik kepada pasien, sikap adil dan tidak membeda-bedakan, perhatian petugas secara khusus kepada pasien dengan mendengarkan dengan seksama keluhan-keluhan pasien serta kesedian petugas meminta maaf dikala membuat kesalahan mendapat respon yang baik dari masyarakat.

\section{B. Saran}

1. Pusat Kesehatan Masyarakat (Puskesmas) di Kota Samarinda khusunya Puskemas Lempake Provinsi Kalimantan Timur harus mampu menjaga fasilitas pelayanan yang sudah ada saat ini agar tetap dalam keadaan yang baik.

2. Tetap mempertahankan dan meningkatkan kualitas pelayanan yang sudah ada.

3. Untuk meningkatkan disiplin kerja bawahannya. Kepala Pusat Kesehatan Masyarakat (Puskesmas) di puskesmas Lempake harus menjalankan fungsinya sebagai motivator dalam meningkatkan semangat pengabdian pegawai terhadap tugasnya.

4. Menjaga agar kondisi ruang pelayanan tetap dalam keadaan yang bersih sehingga masyarakat selalu merasa nyaman.

\section{BIBLIOGRAFI}

Barata, Atep Adya, 2003, Dasar-dasar Pelayanan Prima, PT. Elex Media Komputindo, Jakarta.

Gerson, Richard F., 2002, Mengukur Kepuasan Pelanggan, Terjemahan, PPM, Jakarta.

Kepmen PAN No. 25/M.PAN/2/2004 tentang Pedoman Umum Penyusunan Indeks Kepuasan Masyarakat Unit Pelayanan Instansi Pemerintah. 
Miftah Thoha, 2006 Kepemimpinan Dalam Manajemen Suatu Pendekatan Perilaku, PT. Grafindo Persada, Jakarta.

Moleong, Lexi J., 2000, Metode Penelitian Kualitatif, Remaja Rosdakarya, Bandung.

Moenir, 2001, Manajemen Pelayanan Umum di Indonesia, Jakarta : Bumi Aksara

Ratminto \& Atik SW. 2005. Manajemen Pelayanan : Pengembangan Model Konseptual, Penerapan Citizen's Charter \& SPM. Yogyakarta : Pustaka Pelajar.

Singarimbun, Masri, dan Effendi, Sofian, 2005, Metode Penelitian Survey, Edisi Kedua, LP3ES, Jakarta.

Steers, Richard M., 2005, Efektifitas Organisasi Kaidah Tingkah Laku (terjemahan), Erlangga, Jakarta.

Supranto, J., 2004, Pengukuran Tingkat Kepuasan Pelanggan untuk Menaikkan Pangsa Pasar, Rineka Cipta, Jakarta.

Tjiptono, Fandy, 2002, Manajemen Jasa, Cetkan ketiga, Penerbit Andi, Yogyakarta.

, 2000, Prinsip-prinsip Total Quality (TQS)Yogyakarta : Penerbit Andi

Warella, Y. 2001, Administrasi Negara dan Kualitas Pelayanan Publik Pidato Pengukuhan jabatan Guru Besar Madya ilmu Administrasi Negara. Semarang, Universitas Diponegoro.

Wirawan, 2002, Kapita Selekta Teori Kepemimpinan Pengantar untuk Praktek dan Penelitian, Yayasan Bangun Indonesia \& Uhamka Press, Jakarta.

Zeithaml, Valarie A., (et.al), 2005, Servqual : A Multiple-Item Scale for Measuring Consumer Perceptions of Service Quality dalam Journal of Retailing, Spring.

Zeithaml, Valarie A., (et.al), 2000, Delivering Quality Services : Balancing Customer Perceptions and Expectations, The Free Press, A Division of Macmillan Inc., New York 